\title{
Allergenicity of Food Proteins Interacted with Oxidized Lipids in Soybean-sensitive Individuals
}

\author{
Shoko Doke, Ryo NaKamura and Shinpei Torir* \\ Department of Food Science and Technology, School of Agriculture, \\ Nagoya University, Chikusa-ku, Nagoya 464, Japan \\ * Nagoya University College of Medical Technology, \\ Higashi-ku, Nagoya 461, Japan \\ Received October 14, 1988
}

\begin{abstract}
The allergenicity of proteins interacted with oxidized lipids was examined by enzyme-linked immunosorbent assay (ELISA) using sera from soybean-sensitive individuals. Though oxidized soybean oil did not show any allergenicity, the IgE titer of sera from soybean-sensitive patients was greatly increased when oxidized soybean oil was incubated with soybean $2 S$-globulin. The IgE titer of patient sera became higher when greater amounts of oxidized soybean oil were used. Little difference was noted in the ELISA value of protein interacted with oxidized soybean oil when soybean $2 S$ globulin was replaced by other food proteins. A similar tendency was noted when soybean oil was replaced by other vegetable oils or fatty acids. These results clearly show that proteins interacted with oxidized lipid are allergenic to soybean-sensitive patients.
\end{abstract}

A variety of adverse reactions to soybeans have been reported, $\left.{ }^{1} \sim 4\right)$ but little has been done to isolate and identify the allergens in soybeans responsible for the allergic reactions. Shibasaki et al. ${ }^{5)}$ showed that the 2 S-globulin fraction was the most allergenic of the soy protein components. Moroz and Yang ${ }^{6)}$ also demonstrated that trypsin inhibitor, a member of the 2S-globulin fraction, was an allergen in one patient having severe allergic reactions to soybean products, although soybean-trypsininhibitor-specific radioallergosorbent tests (RASTs) were negative in two other patients with soybean allergy. Recently, Burks et al. ${ }^{7}$ demonstrated that no one fraction of soybean proteins was more allergenic than others. Soybean contains up to $20 \%$ lipid, but soybean oil was shown not to be allergenic in doubleblind challenge tests with soybean-allergic individuals. ${ }^{8}$ Many more studies should be done to identify the allergens from soybeans.

It was shown that autoxidized lipids could interact with various kinds of proteins. ${ }^{91}$ There is a possibility that soybean oil is oxidized and interacts with proteins during the processing of foods. Proteins interacted with oxidized soy- bean oil might be the cause of allergenicity.

In this work, the allergenicity of the proteins interacted with oxidized lipids was studied using an enzyme-linked immunosorbent assay (ELISA).

\section{Materials and Methods}

Materials. Soybean oil, rapeseed oil, and peanut oil were obtained from Katayama Chemical Co., Ltọ. (Osaka, Japan). Oleic acid, linoleic acid, and linolenic acid were purchased from Wako Chemical Industries. These lipids were autoxidized in the open air at $40^{\circ} \mathrm{C}$ for three days. The preparations contained hydroperoxides and their secondary degraded products. Ovalbumin (type V), conalbumin (type II), and $\beta$-lactoglobulin (type A \& B) were purchased from the Sigma Chemical Co. Soybean $2 S-$ globulin was prepared from defatted soybeans produced in Indiana, USA by the procedure of Koshiyama et al. ${ }^{10)}$

Reaction between proteins and oxidized lipids. Oxidized lipids were reacted with proteins under the conditions described by Shimada and Matsushita. ${ }^{11}$ Briefly, in $10 \mathrm{ml}$ of water containing $0.02 \mathrm{M} \mathrm{NaN}_{3}, 0.5 \mathrm{~g}$ of protein was dissolved and adjusted to $\mathrm{pH} 7.0$ with $1 \mathrm{~N} \mathrm{NaOH}$. To the protein solution, $0.5 \mathrm{ml}$ of oxidized lipids was added. After stirring, the solution was shaken at $40^{\circ} \mathrm{C}$ for a definite time ranging from 1 to 5 days. The reaction solution was lyophilized after defatting with ethanol. 
Enzyme-linked immuno-sorbent assay (ELISA). The allergenic activity of proteins interacted with oxidized lipids was investigated by enzyme-linked immunosorbent assay (ELISA). ${ }^{12)}$ Flat-bottomed microtiter-plates (Costar, Cambridge, MA) were coated with an appropriate concentration of antigen $(2 \sim 10 \mu \mathrm{g} / \mathrm{ml})$, and human sera that reacted with the plate-bound antigen were measured using peroxidase-coupled anti-human IgE antibody (Cappel Labs. Inc. Cochranville, PA) with $\sigma$-phenylenediamine as the enzyme substrate (Matsuda et al.) ${ }^{13)}$ Sera with high RAST scores against soybeans were selected from the sera of patients with known clinical histories of allergies.

For the competitive inhibitor assay, $100 \mu 1$ of competitive inhibitor solution and $50 \mu$ l of the patient's serum (1:200 dilution) to soybean were added to the wells coated with ovalbumin interacted with oxidized linoleic acid. The plates were incubated at $37^{\circ} \mathrm{C}$ for $3 \mathrm{hr}$, and the antibodies reacted with the plate-bound antigen were measured as above.

Analytical methods. Protein was meaured by the method of Lowry et al. ${ }^{14)}$ Amino acids were analyzed with a type JLC-6AH amino acid analyzer (JEOL, Tokyo) after hydrolysis at $110^{\circ} \mathrm{C}$ for $24 \mathrm{hr}$ in $6 \mathrm{~N} \mathrm{HCl}$ in evacuated, sealed tubes.

Peroxide value (POV) was measured by the thiocyanate method. ${ }^{15)}$ Briefly, a sample was added to $4.7 \mathrm{ml}$ of $75 \%$ ethanol and $0.1 \mathrm{ml}$ of $30 \%$ ammonium thiocyanate. After stirring, the solution was added to $0.1 \mathrm{ml}$ of a filtrate of $\mathrm{BaCl}_{2}$ solution $(0.5 \mathrm{~g} / 50 \mathrm{ml})$ to which were added $\mathrm{FeSO}_{4}$ solution $(0.6 \mathrm{~g} / 50 \mathrm{ml})$ and $\mathrm{HCl}(10 \mathrm{ml})$, and then the absorbance at $500 \mathrm{~nm}$ was measured $3 \mathrm{~min}$ later.

\section{Results and Discussion}

No difference of IgE titer for 2S-globulin fractions could be found between patients' and normal individuals' sera (data not shown). Addition of soybean oil to the $2 \mathrm{~S}$-globulin fraction did not affect the ELISA results when the soybean oil was not autoxidized. The $\operatorname{IgE}$ titer of patients' sera, however, was greatly increased when soybean oil preincubated at $40^{\circ} \mathrm{C}$ for 3 days was added to the $2 \mathrm{~S}$-globulin fraction (Fig. 1). Three patients' sera used in this experiment gave definitely high IgE titers compared with three normal sera. Since oxidized lipids were shown to interact with various kinds of protein, ${ }^{9)}$ this result suggests that a specific IgE might be produced against the $2 \mathrm{~S}-$ globulin fraction interacted with oxidized soybean oil. If this is the case, the IgE titer of patients' sera should be high when soybean

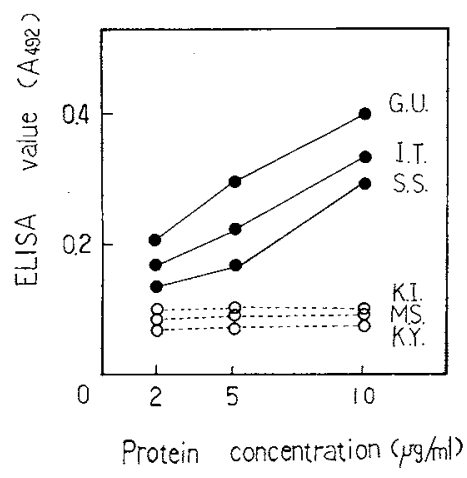

Fig. 1. ELISA Values of 2S-Globulin Fraction Interacted with Oxidized Soybean Oil in the Sera from Three Soybean-allergic Patients (O, G.U., I.T., S.S.) and Three Non-allergic Persons (O, K.I., M.S., K.Y.).

ELISA reaction time, $60 \mathrm{~min}$.

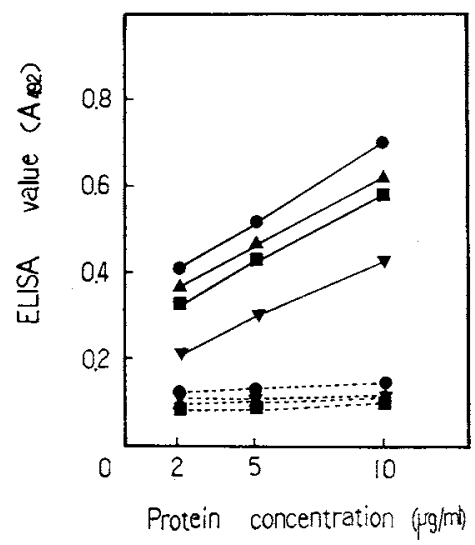

Fig. 2. ELISA Values of Protein Interacted with Oxidized Soybean Oil (, , Ovalbumin; $\boldsymbol{\Delta}$, Conalbumin; $\beta$-Lactoglobulin; $\boldsymbol{\nabla}, 2 \mathrm{~S}-$ Globulin) in Patients' (-) and Normal (-----) Sera.

ELISA reaction time, $60 \mathrm{~min}$.

2S-globulin fraction is replaced by other protein. To ascertain this hypothesis, ovalbumin, $\beta$-lactoglobulin, and conalbumin were interacted with oxidized soybean oil, and their $\operatorname{IgE}$ titer was measured against the serum of one patient (G.U.) using ELISA. Figure 2 clearly shows that the IgE titer of patient serum for all proteins was higher than that of normal serum when oxidized soybean oil was added.

Soybean oil contains a large amount of linolenic acid and is easily oxidized. ${ }^{16)}$ This susceptibility of soybean oil to oxidation might 


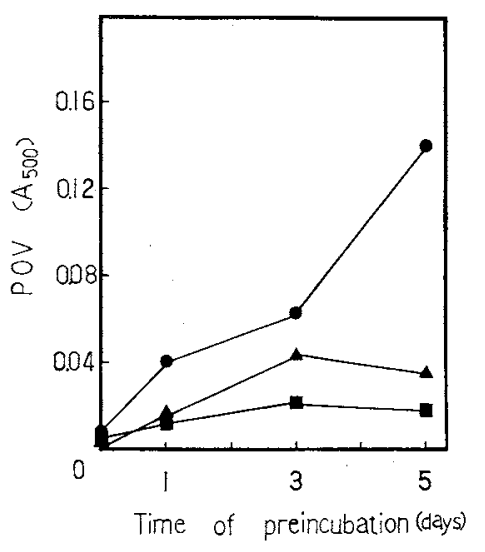

Fig. 3. Peroxide Values (POV) of Vegetable Oils Soybean; $\boldsymbol{\Delta}$, Peanut; $\mathbf{\square}$, Rapeseed) Preincubated at $40^{\circ} \mathrm{C}$ for 0 to 5 Days.

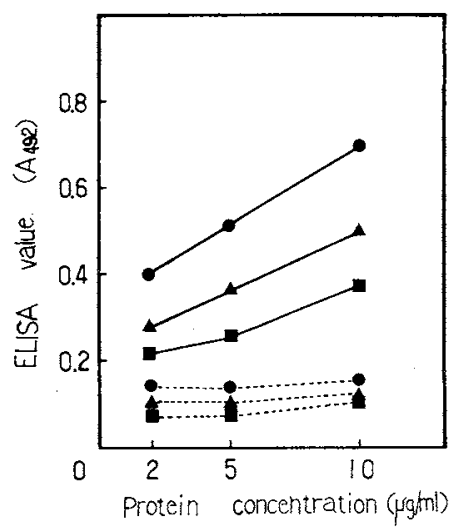

Fig. 4. ELISA Values of Ovalbumin Interacted with Oxidized Vegetable Oils ( $\boldsymbol{0}$, Soybean; $\boldsymbol{\Delta}$, Peanut; Rapeseed) Preincubated for 3 Days in Patients' (- - ) and Normal (------) Sera.

ELISA reaction time, $60 \mathrm{~min}$.

be related to the high IgE titer of patients' serum for the proteins interacted with oxidized soybean oil. Since the amounts of linoleic acid and linolenic acid in peanut oil and rapeseed oil are much smaller than those in soybean oil, the degree of allergenicity of a protein interacted with these oils might be lower than that of soybean oil. Figure 3 shows that the peroxide values of both peanut oil and rapeseed oil at all the incubation times were much smaller than those of soybean oil. As shown in Fig. 4 , the IgE titer of patient serum against

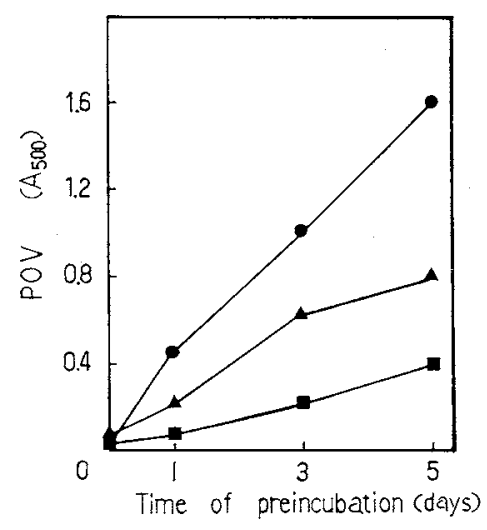

Fig. 5. Peroxide Values (POV) of Fatty Acids Linolenic; $\boldsymbol{\Lambda}$, Linoleic; $\boldsymbol{\square}$, Oleic Acid) Preincubated at $40^{\circ} \mathrm{C}$ for 0 to 5 Days.

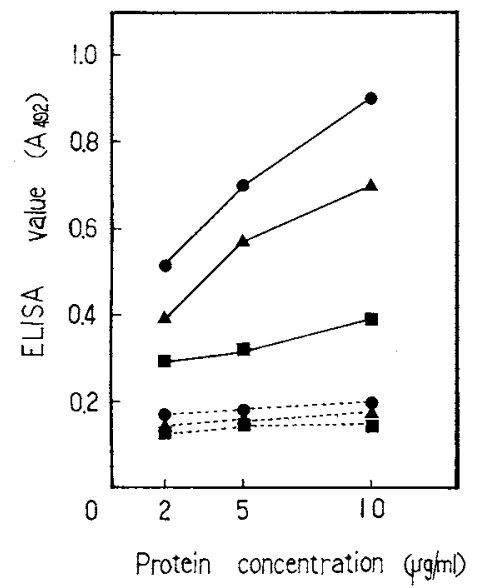

Fig. 6. ELISA Values of Ovalbumin Interacted with Oxidized Fatty Acids (O, Linolenic; $\boldsymbol{\Delta}$, Linoleic; $\mathbf{D}$, Oleic Acid) Preincubated for 3 Days in Patients' ( - ) and Normal (-----) Sera.

ELISA reaction time, $60 \mathrm{~min}$.

ovalbumin interacted with these two kinds of vegetable oil was much smaller than that against ovalbumin interacted with soybean oil.

A similar tendency was also noted in ELISA experiments using ovalbumin interacted with oxidized fatty acids; the peroxide value of fatty acids increased during incubation in the order of linolenic acid, linoleic acid, and oleic acid (Fig. 5), and the IgE titer of the patient serum against ovalbumin interacted with oxidized fatty acids increased in the same order (Fig. 6). 


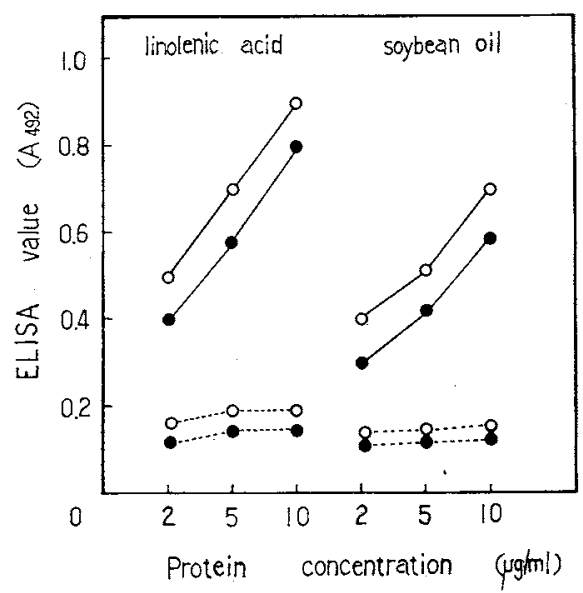

Fig. 7. Effects of Lipid Oxidation Time on the ELISA Values of Ovalbumin Interacted with Oxidized Lipid in Patients' (-) and Normal (-....-) Sera.

Lipid oxidation time, 1 day $(-)$ or 3 days $(O-O)$. ELISA reaction time, $60 \mathrm{~min}$.

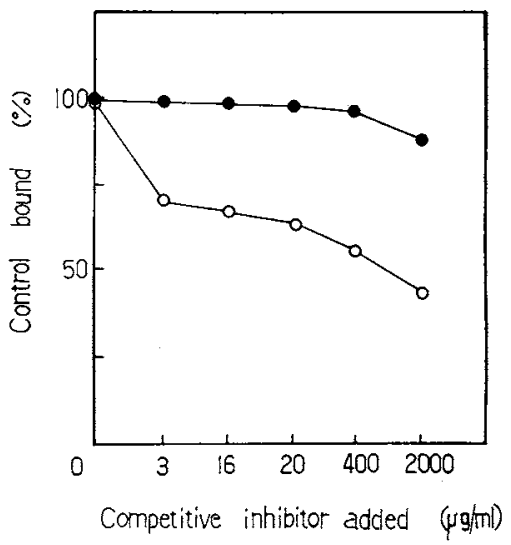

Fig. 8. Competitive Inhibition of Binding between Ovalbumin Interacted with Oxidized Linoleic Acid and Its Specific Antibody by Native Protein.

The binding between the plate-bound antigen $(5 \mu \mathrm{g} / \mathrm{ml})$ and serum antibodies was inhibited by various amounts of ovalbumin interacted with oxidized linoleic acid $(\mathrm{O}-\mathrm{O})$ but not inhibited by ovalbumin

The degree of oxidation in lipids also affected the degree of allergenicity of protein interacted with the oxidized lipid. Either soybean oil or linoleic acid was incubated 1 and 3 days at $40^{\circ} \mathrm{C}$, and the $\operatorname{IgE}$ titer of patient serum was measured against ovalbumin interacted with these preincubated lipids (Fig. 7). The IgE titer against ovalbumin interacted with either linoleic acid or soybean oil incubated for 3 days was larger than that from a 1-day incubation.

The specificity of antibody toward the protein interacted with oxidized linoleic acid was examined by ELISA competitive inhibition analysis (Fig. 8). It was noted that the ovalbumin interacted with oxidized linoleic acid had a high specificity of antigen binding.

All these experiments clearly show that a specific IgE is produced against proteins interacted with oxidized lipids. Polyunsaturated fatty acids react easily with atmospheric oxygen to form their hydroperoxides, which are broken down in the presence of oxygen and give a mixture of further oxidized products. ${ }^{17)}$ The latter products are so reactive that they may interact with protein and change its properties. Interaction of these oxidized products with some proteins has been studied. ${ }^{18 \sim 20)}$ In this work, we could not show any special compounds interacting with protein, but the allergenicity of protein interacted with oxidized lipid would depend on these compounds.

To investigate the oxidized products of lipids which cause the allergenicity reaction with patient serum, further experiments are planned in this laboratory.

Acknowledgment. This study was supported in part by a Grant-in-Aid for Scientific Research (No. 63560125) from the Ministry of Education, Science and Culture of Japan.

\section{References}

1) C. D. Cook, New England J. Med., 263, 1076 (1960).

2) W. W. Duke, J. Allergy, 5, 300 (1934).

3) I. Jakobson and T. Lindberg, Acta Paediatr. Scand., 68, 853 (1979).

4) H. A. Sampson and C. M. McCaskill, J. Pediatr., 107, 669 (1985).

5) M. Shibasaki, S. Suzuki, S. Tajima and H. Kuroume, Int. Arch. Allergy Appl. Immunol., 61, 441 (1980).

6) L. A. Maroz and W. H. Yang, N. Eng. J. Med., 302, $1126(1980)$.

7) A. W. Burks Jr. and J. R. Brooks, J. Allergy Clin. Immunol., 81, 1135 (1988).

8) R. K. Bush and S. L. Taylor, J. Allergy Clin. Immunol., 73, 176 (1984) 
9) S. Matsushita, Agric. Biol. Chem., 42, 781 (1978).

10) I. Koshiyama, Int. J. Peptide Protein Res., 4, 167 (1972).

11) K. Shimada and S. Matsushita, Agric. Biol. Chem., 42, 781 (1978).

12) E. Engvall and P. Perlmann, Immunochemistry, 8, 871 (1971).

13) T. Matsuda, K. Watanabe and R. Nakamura, Biochem. Biophys. Res. Commun., 193, 265 (1981).

14) O. H. Lowry, N. J. Rosebrough, A. L. Farr and R. J. Randall, J. Biol. Chem., 193, 265 (1951).

15) H. Mitsuda, K. Yasumoto and K. Iwami, Eiyo to
Shokuryo, 19, 210 (1966).

16) J. M. DeMan, "Principles of Food Chemistry," Avi Publ. Comp., Inc. Westport, Connecticut, 1980, p. 47.

17) D. L. Crawford, T. C. Yu and R. O. Sinnhuber, J. Food Sci., 32, 332 (1967).

18) H. Chiba, H. Doi, M. Yoshikawa and E. Sugimoto, Agric. Biol. Chem., 40, 1001 (1976).

19) K. S. Chio and A. L. Tappel, Biochemistry, 8, 2827 (1969).

20) K. Kanazawa, H. Ashida and M. Natake, J. Food Sci., 52, 475 (1987). 